\title{
PENERAPAN MODEL PEMBELAJARAN CONTEXTUAL TEACHING AND LEARNING (CTL) UNTUK MENINGKATKAN KEAKTIFAN DAN HASIL BELAJAR SISWA AGAMA BUDDHA PADA MATERI PANCASĪLA BUDDHIS KELAS VII SMP N 2 KELING KABUPATEN JEPARA
}

\author{
Nopiyanti, Mujiyanto, Sujiono \\ STAB Negeri Raden Wijaya Wonogiri Jawa Tengah \\ Vhya_Ovie@yahoo.com
}

\begin{abstract}
There are students active in learning when asked by the teacher. They often do not understand to what has been delivered even shy to ask questions, express ideas or refutation as well as the value of the study of students is still less than the maximum. This is the reason why the researchers conduct this research with the aim that by applying the Contextual Teaching and Learning (CTL) model may enhance the activity and learning outcomes of students of class VII SMPN 2 Keling. This is a classroom action research (PTK) methods in SMP N 2 Keling. The subjects were 10 the Buddhist students of Class VII. The study consisted of two cycles each cycle has four main parts; 1) planning; 2) the action; 3) observations; 4) reflection. Moreover, to control the learning activities used some instruments they are observation sheets, interview and tests. This research used descriptive qualitative and descriptive quantitative analysis techniques. The results of this study concluded that: 1) the application of Contextual Teaching and Learning (CTL) models may enhance the activity of Buddhist students in the Buddhist Pancasila material class VII SMPN 2 Keling. This is activated by applying the learning components of Contextual Teaching and Learning (CTL) model in the learning activities in each cycle. In the first cycle, there are three students get good criteria while in the second cycle, all students get good criteria. 2) The application of learning Contextual Teaching and Learning (CTL) models can improve learning outcomes of students in Buddhism education the Buddhist Pancasila material in class VII SMPN 2 Keling. The application of the Contextual Teaching and Learning (CTL) model improve the learning outcomes of students by increasing minimum limit completion over cycle. In the first cycle, there are 7 students $(70 \%)$ reach the minimum limit value, previously in the pre-cycle, there are only 4 students (40\%) who reach the limit value of completion. There is increase on $30 \%$. In the second cycle, they are 10 student $(100 \%)$ who have reached the minimum limit value. It means there is increasion of 3 student $(30 \%)$.
\end{abstract}

Keywords: Contextual Teaching and Learning (CTL) model, learning activeness, student learning outcomes.

\begin{abstract}
ABSTRAK
Peserta didik dalam belajar ada yang aktif ada yang tidak ketika ditanya oleh guru. Peserta didik sering tidak paham terhadap apa yang sudah disampaikan bahkan malu untuk bertanya, menyampaikan ide atau sanggahan serta nilai hasil belajar peserta didik masih kurang maksimal. Hal ini yang menjadi alasan peneliti untuk melakukan penelitian dengan tujuan bahwa dengan menerapkan model pembelajaran Contextual Teaching and Learning (CTL) dapat meningkatkan keaktifan dan hasil belajar peserta didik kelas VII di SMPN 2 Keling. Penelitian ini merupakan jenis Penelitian Tindakan Kelas (PTK) yang dilakukan di SMP N 2 Keling. Subyek penelitian ini adalah peserta didik Kelas VII yang berjumlah 10 peserta didik. Penelitian ini terdiri dari dua siklus yang setiap siklus mempunyai empat bagian utama yaitu; 1) perencanaan; 2) tindakan; 3) pengamatan (observasi); 4) refleksi. Selain itu juga untuk mengontrol kegiatan pembelajaran digunakan beberapa instrumen yaitu lembar observasi, pedoman wawancara dan soal tes. Penelitian ini menggunakan teknik analisis data deskriptif kualitatif dan deskriptif kuantitatif. Hasil penelitian ini menyimpulkan bahwa: 1) penerapan model pembelajaran Contextual Teaching and Learning (CTL) dapat meningkatkan keaktifan peserta didik agama Buddha pada materi Pancasīla Buddhis kelas VII SMPN 2 Keling. Hal tersebut dilakukan dengan cara menerapkan komponen Pembelajaran Contextual Teaching and Learning (CTL) dalam kegiatan pembelajaran pada setiap siklus. Pada siklus I tiga peserta didik yang
\end{abstract}


mendapatkan kriteria baik dan pada siklus II semua peserta didik mendapatkan kriteria baik. 2) Penerapan model pembelajaran Contextual Teaching and Learning (CTL) dapat meningkatkan hasil belajar peserta didik agama Buddha pada materi Pancasīla Buddhis kelas VII SMPN 2 Keling. Penerapan model Contextual Teaching and Learning (CTL) meningkatkan hasil belajar peserta didik dengan mencapai batas tuntas minimal terus meningkat dari tiap siklus. Pada siklus I mencapai nilai batas minimal sebanyak 7 peserta didik (70\%), sebelumnya saat pra siklus peserta didik yang mencapai nilai batas tuntas minimal sebanyak 4 (40\%). Terjadi peningkatan (30\%). Pada siklus II peserta didik yang telah mencapai nilai batas tuntas minimal sebanyak 10 peserta didik (100\%) terjadi peningkatan sebanyak 3 peserta didik (30\%).

Kata Kunci: Model Contextual Teaching and Learning (CTL), Keaktifan Belajar, Hasil Belajar siswa.

\section{PENDAHULUAN}

Menurut Sanjaya (2006: 59) mengemukakan bahwa kegiatan pembelajaran melibatkan berbagai komponen: (1) Peserta didik: seorang yang bertindak sebagai pencari, penerima, dan penyimpan isi pelajaran yang dibutuhkan untuk mecapai tujuan. (2) Guru: seseorang yang bertindak sebagai pengelola, sumber belajar dan peran lainnya yang memungkinkan terciptanya kegiatan pembelajaran yang efektif. (3) Tujuan: perubahan tingkah laku baik kognitif, afektif dan psikomotorik yang di inginkan peserta didik setelah terjadinya kegiatan pembelajaran. (4) Isi pelajaran: berbagai informasi yang diterima sebagai pengetahuan yang nanti diperlukan untuk mencapai suatu tujuan. (5) Metode: cara yang digunakan untuk memberikan informasi agar peserta didik dengan mudah menerima apa yang disampaikan sehingga tujuan dapat tercapai. (6) media: bahan atau alat yang digunakan untuk menyajikan informasi kepada peserta didik. (7) evaluasi: cara tertentu yang digunakan untuk menilai suatu keberhasilan kegiatan pembelajaran.

Penggunaan model pembelajaran merupakan serangkaian dari kegiatan pembelajaran yang digunakan seorang guru untuk menyampaikan informasi dan menjadi faktor penentu keberhasilan dalam kegiatan belajar mengajar di sekolah. Model pembelajaran yang monoton atau belum variatif seperti metode ceramah saja akan membuat pembelajaran tidak menyenangkan, peserta didik cepat bosan.

Keberhasilan dalam proses pembelajaran juga dipengaruhi oleh metode yang digunakan guru, karena guru masih menggunakan metode monoton belum sepenuhnya menggunakan model pembelajaran yang kontekstual, waktu belajar peserta didik masih didominasi oleh guru, belum melibatkan peserta didik secara aktif, penyampaian materi masih bersifat teoritis, guru belum mengaitkan dengan masalah yang dihadapi seharihari, penilaian keberhasilan peserta didik hanya menekankan pada pengetahuan tidak melihat sikap dalam proses belajar.

Berdasarkan hasil wawancara pada hari Jumat tanggal 18 Desember 2015 dengan Guru Pamong Pendidikan Agama Buddha diperoleh hasil bahwa; peserta didik dalam belajar dikelas sering sibuk dengan aktivitas mereka sendiri, ada yang aktif ada yang tidak, ketika ditanya oleh guru peserta didik sering tidak paham terhadap apa yang sudah disampaikan bahkan malu untuk bertanya, menyampaikan ide atau sanggahan Selain itu, guru belum sepenuhnya menggunakan model pembelajaran yang kontekstual dalam kegiatan pembelajaran agama Buddha, guru masih 
menggunakan metode ceramah saja atau satu arah sehingga guru aktif tetapi peserta didik pasif, penyampaian materi yang diajarkan hanya mengikuti panduan dibuku pelajaran saja kurangnya keterkaitan antara materi dengan permasalahan yang nyata, sehingga peserta didik sulit memahami konsep materi. Sebagian peserta didik di SMP N 2 Kelinga di Jepara nilai yang diperoleh peserta didik masih dibawah KKM yang ditetapkan yaitu 7,6 dari keadaan seperti itu akan berdampak pada keberhasilan tujuan pembelajaran.

Beberapa upaya telah dilakukan untuk mengatasi permasalahan di atas salah satunya adalah dengan menerapkan model pembelajaran Contextual Teaching and Learning ( CTL) dalam kegiatan pembelajaran yang membantu guru mengaitkan antara materi yang diajarkan dengan situasi dunia nyata peserta didik. Menurut Sanjaya (2006: 255) Pembelajaran CTL (Contextual Teaching and Learning) merupakan strategi yang melibatkan peserta didik secara penuh dalam kegiatan pembelajaran.

Melihat keadaan tersebut mendorong peneliti untuk melakukan penelitian dengan harapan melalui penerapan model Pembelajaran Contextual Teaching and Learning (CTL) pada saat pembelajaran pada pendidikan agama Buddha mampu meningkatkan keaktifan dan hasil belajar peserta didik. Oleh karena itu, penulis mengadakan penelitian dengan judul "Penerapan Model Pembelajaran Contextual Teaching and Learning (CTL) untuk Meningkatkan Keaktifan dan Hasil Belajar Peserta didik Agama Buddha pada Materi Pancasīla Buddhis Kelas VII di SMP N 2 Keling Kabupaten Jepara "

\section{Contextual Teaching and Learning (CTL)}

\section{Pengertian Contextual Teaching and Learning} (CTL)

Pembelajaran Contextual Teaching and Learning (CTL) merupakan strategi yang melibatkan peserta didik secara penuh dalam proses pembelajaran. Belajar melalui Contekstual Teaching and Learning (CTL) peserta didik diharapkan dapat menemukan sendiri materi yang dipelajarinya. (Sanjaya, 2006: 255).

\section{Karakteristik Contekstual Teaching and}

\section{Learning (CTL)}

Karakteristik Contextual Teaching and Learning yang dikemukakan oleh Hanafiah dan Suhana (2012: 69) yaitu (1) kerjasama antarpeserta didik dan guru (cooperative), (2) saling membantu antarpeserta didik dan guru (assist), (3) belajar dengan bergairah (enjoyful learning), pembelajaran terintegrasi secara kontekstual, (5) menggunakan multi media dan sumber belajar, (6) cara belajar peserta didik aktif (student active learning), (7) sharing bersama teman (take and give), (8) peserta didik kritis dan guru kreatif, (9) dinding kelas dan lorong kelas penuh dengan karya peserta didik, (10) laporan peserta didik bukan hanya buku lapor, tetapi juga hasil karya peserta didik, laporan hasil praktikum, karangan peserta didik dan sebagainya.

\section{Komponen Pembelajaran Contextual}

\section{Teaching and Learning (CTL)}

Menurut Riyanto (2009: 170) pendekatan Contextual Teaching and Learning (CTL) melibatkan tujuh komponen utama pembelajaran efektif, yakni:

\section{a. Konstruktivisme (Constructivism)}

Menurut Riyanto (2009: 171) menjelaskan bahwa pengetahuan dibangun oleh manusia sedikit demi, 
yang hasilnya diperluas melalui konteks yang terbatas dan tidak sekonyong-konyong.

b. Bertanya (questioning)

Kemampuan yang dimiliki peserta didik tidak lepas dari kegiatan bertanya. Saat pembelajaran, melalui bertanya mampu mendorong guru untuk membimbing, menilai dan mengetahui sejauhmana daya serap peserta didik terhadap materi yang diajarkan. Bagi peserta didik, bertanya menunjukkan adanya perhatian terhadap materi yang dipelajari dan ada upaya untuk menemukan jawaban sebagai bentuk pengetahuan. Bagi guru, bertanya adalah upaya mengaktifkan peserta didik (Sardiman, 2011: 224).

\section{c. Menemukan (Inquiry)}

Komponen ketiga dalam pembelajaran CTL adalah inquiri. Artinya, proses pembelajaran didasarkan pada pencarian dan penemuan melalui proses berpikir secara sistematis.

\section{d. Masyarakat Belajar (Learning Community)}

Penerapan pendekatan Contextual Teaching and Learning (CTL) guru disarankan selalu melaksanakan pembelajaran secara kelompok.

e. Pemodelan (Modelling)

Asas Modeling adalah proses pembelajaran dengan memperagakan sesuatu sebagai contoh yang dapat ditiru oleh setiap peserta didik.

\section{f. Refleksi (Reflection)}

Refleksi (Reflection) adalah berpikir tentang apa yang baru dipelajari kebelakang tentang apa-apa yang sudah dilakukan masa lalu (Riyanto, 2009: 176).

g. Penilain sebenarnya (Authentic Assessment).

Sardiman (2011: 228) menjelaskan penilaian adalah proses pengumpulan data yang memberikan gambaran perkembangan belajar peserta didik.
4. Perbedaan pembelajaran Contextual Teaching and Learning (CTL) dengan Kovensional

Perbedaan model pembelajaran Contextual Teaching and Learning (CTL) dengan model pembelajaran konvensional adalah peran peserta didik pencari informasi sedangkan pada pembelajaran konvensional peserta didik hanya sebagai penerima informasi sehingga kegiatan proses pembelajaran menjadi kaku dan peserta didik hanya menerima saja apa yang disampaikan guru di kelas.

5. Keunggulan Model Contextual Teaching and Learning (CTL)

Keunggulan penerapan model CTL dalam pembelajaran, yaitu sebagai berikut (Fauziyah: 2012):
a. Real world learning
b. Mengutamakan pengalaman dalam kehidupan nyata peserta didik
c. Proses berpikir tingkat tinggi
d. Student centered
e. Peserta didik aktif, kritis, dan kreatif
f. Realistis
g. Peserta didik langsung melakukan bukan menghafal teori
h. Proses yang terjadi adalah learning bukan teaching
i. Education yang terjadi bukan Intruction.
j. Pembentukan pribadi peserta didik
k. Peserta didik dapat memecahkan masalah
1. Peserta didik menjadi model
m. Hasil belajar diukur dengan berbagai alat ukur bukan hanya tes.

\section{Langkah- langkah Pembelajaran Contextual}

Teaching and Learning (CTL) 
Majid (2014: 225) secara garis besar langkahlangkah penerapan pembelajaran CTL yaitu sebagai berikut:

a. Kembangkan pemikiran bahwa anak akan belajar lebih bermakna dengan cara bekerja sendiri, dan mengkontruksi sendiri pengetahuan dan keterampilan barunya;

b. Laksanakan sejauh mungkin kegiatan inkuiri untuk semua topik;

c. Kembangkan sifat ingin tahu peserta didik dengan bertanya;

d. Ciptakan masyarakat belajar;

e. Hadirkan model sebagai contoh pembelajaran;

f. Lakukan refleksi di akhir pertemuan;

g. Lakukan penilaian yang sebenarnya dengan berbagai cara.

\section{Keaktifan Belajar}

\section{Pengertian Keaktifan Belajar}

Keaktifan menurut Kamus Terbaru Bahasa Indonesia (2008: 30) berarti kesibukan, kegiatan.

\section{Klasifikasi keaktifan}

Diedrich dalam Sardiman (2004: 100) menggolongkan aktivitas belajar peserta didik terdiri dari delapan macam yaitu:
a. Visual Aktivities,
b. Oral Aktivities,
c. Listening Aktivities,
d. Writing Aktivities
e. Drawing Aktivities
f. Motor Aktivities,
g. Mental Aktivities,
h. Emosional

\section{Hasil belajar}

\section{Pengertian Hasil Belajar}

Hasil belajar merupakan output dari proses pembelajaran yang telah dilakukan oleh guru kepada peserta didik. "Hasil belajar merupakan kemampuan-kemampuan yang dimiliki peserta didik setelah menerima pengalaman belajar". (Sudjana, 2012: 22). .

\section{Faktor yang Mempengaruhi Hasil Belajar}

Faktor- faktor yang mempengaruhi hasil belajar menurut Slameto (2010: 54) adalah sebagai berikut:

a. Faktor Internal

1). Faktor Fisiologis

Faktor fisiologis meliputi keadaan kesehatan yang prima, tidak dalam keadaan lelah, tidak dalam keadaan cacat jasmani dan sebagainya.

2). Faktor psikologis

a). Intelegensi

b). Perhatian

c). Minat dan Bakat

d). Motif

e). Kematangan dan kesiapan

b. Faktor Eksternal

1). Faktor lingkungan

2). Faktor instrumental

\section{Tujuan Melakukan Penilaian Hasil Belajar}

Menurut Kunandar (2014: 70) tujuan guru melakukan penilaian hasil belajar terhadap peserta didik adalah sebagai berikut:

a. Melacak kemajuan belajar peserta didik.

b. Mengecek ketercapaian kompetensi peserta didik

c. Mendeteksi kompetensi yang belum diketahui oleh peserta didik.

d. Sebagai umpan balik untuk perbaikan bagi peserta didik.

\section{Cara Melakukan Penilaian Hasil Belajar}

Terdapat beberapa teknik atau cara untuk melalukan evaluasi pembelajaran untuk mengetahui hasil 
belajar yaitu teknik tes dan teknik nontes. Pada penelitian ini peneliti menggunakan teknik tes .

Amir Dalen Indrakusuma dalam Arikunto (2012: 46). Ditinjau dari segi kegunaan untuk mengukur kemampuan peserta didik tes dibedakan menjadi tiga yaitu:

a. Tes Diagnostik

b. Tes Formatif

c. Tes Sumatif

\section{Kerangka Berpikir}

Kondisi awal Pada proses pembelajaran agama Buddha pada materi Pancasīla Buddhis kelas VII SMP N 2 Keling guru masih menggunakan metode yang monoton atau kurang variatif, belum mengaitkan materi dengan pengalaman peserta didik, dan pembelajaran masih didominasi oleh guru. ada yang aktif ada yang tidak, sehingga kekatifan dan hasil belajar siswa menjadi rendah.

Rendahnya keaktifan dan hasil belajar siswa kelas VII SMP N 2 Keling merupakan suatu permasalahan sehingga diberikan tindakan dengan menerapkan model pembelajaran model Contextual Teaching and Learning (CTL). Penerapan model Contextual Teaching and Learning (CTL) dalam proses pembelajaran memberikan hasil yang baik terhadap pemahaman materi karena dikaitkan dengan pengalaman peserta didik. Hasil penerapan model Contextual Teaching and Learning (CTL) mampu meningkatkan keaktifan peserta didik dalam proses pembelajaran pendidikan agama Buddha, dan juga hasil belajar siswa meningkat yaitu dengan pencapaian satandar minimal ketuntasan diatas $76 \%$.

\section{Hipotesis Tindakan}

Berdasarkan tinjauan teori dan kerangka berpikir yang telah peneliti ungkapkan di atas, maka peneliti ini dapat merumuskan suatu hipotesis yaitu:

1. Penerapan model pembelajaran Contextual Teaching and Learning (CTL) di SMP N 2 Keling dapat meningkatkan keaktifan belajar peserta didik agama Buddha pada materi Pancasīla Buddhis.

2. Penerapan model pembelajaran Contextual Teaching and Learning (CTL) di SMP N 2 Keling dapat meningkatkan hasil belajar peserta didik agama Buddha pada materi Pancasīla Buddhis.

3. Penerapan komponen model Contextual Teaching and Learning (CTL) di SMP N 2 Keling dapat meningkatkan keaktifan dan hasil belajar peserta didik agama Buddha pada materi Pancasīla Buddhis.

\section{METODE PENELITIAN}

\section{A. Jenis dan Desain Penelitian}

Penelitian ini merupakan Classroom Action Research di singkat dengan CAR atau Penelitian Tindakan Kelas (PTK). Desain penelitian ini menggunakan desain penelitian yang dikembangkan oleh Kurt Lewin dalam Arikunto, S (2013: 131). yang terdiri dari 4 komponen yang merupakan proses tahapan, yaitu tahap Perencanaan (Planing), Tindakan (Acting), Pengamatan (Observing), dan Refleksi (Reflecting). Penelitian ini dilaksanakan di SMPN 2 Keling, yang beralamat di Jalan Raya Tunahan-Keling Km. 35 Jepara, Jawa Tengah.

\section{B. Tahapan Penelitian Tindakan Kelas (PTK)}

\section{Tahap pra tindakan}


Tahapan pra tindakan dilakukan peneliti untuk mengetahui situasi dan kondisi belajar peserta didik kelas VII SMPN 2 Keling beragama Buddha. Kegiatan ini dilakukan dengan wawancara kepada Guru Pendidikan agama Buddha dan juga Peserta didik kelas VII yang beragama Buddha serta melakukan observasi terhadap kegiatan pembelajaran di SMPN 2 Keling pada pendidikan agama Buddha kelas VII.

\section{Tahap Tindakan}

a. Siklus I
1) Perencanaan
2) Pelaksanaan
3) Observasi
4) Refleksi

b. Siklus II
1) Perencanaan
2) Pelaksanaan
3) Observasi
4) Refleksi

\section{PEMBAHASAN}

\section{A. Deskripsi Kondisi Awal}

Data dari kondisi awal yaitu berupa hasil Pre Test sebelum penerapan model pembelajaran Contextual Teaching and Learning (CTL). Kompetensi Kelulusan Minimum (KKM) pada pendidikan agama Buddha di SMP Negeri 2 Keling Kelas VII adalah 76. Berdasarkan hasil Pre Test yang diperoleh dari 10 peserta didik masih ada yang belum tuntas dengan nilai di bawah KKM.

\section{B. Deskripsi Siklus I}

\section{Perencanaan siklus I}

Perencanaan tersebut diantaranya menyusun Rencana Pelaksanaan Pembelajaran (RPP) dengan metode Contextual Teaching and Learning, menyususn instrumen tes meliputi pre test dan post test, menyusun lembar observasi proses pembelajaran, lembar observasi keaktifan peserta didik, serta lembar wawancara pada guru dan peserta didik.

\section{Pelaksanaan Siklus I}

a) Pertemuan pertama

Pada pertemuan pertama guru membuka kegiatan pembelajaran dengan salam Doa Namakārapātha, mengabsensi peserta didik, serta melakukan apersepsi berkaitan dengan keaktifan peserta didik dalam kegiatan keagamaan di rumah. Kemudian peneliti berkolaborasi dengan guru untuk memberikan soal pre test.

b) Pertemuan kedua

Pada pertemuan yang kedua guru melaksanakan proses belajar mengajar pendidikan agama Buddha pada materi Pancasila Buddhis dengan menerapkan metode Contextual Teaching and Learning (CTL), Kegiatan pembelajaran pada pertemuan kedua ini berlangsung selama $2 \mathrm{x}$ 40 menit diawali dengan membacakan Doa Namarapatha, menyampaikan tujuan pembelajaran, menyampaikan motivasi dan mengadakan apersesi.

Kegiatan selanjutnya adalah kegiatan inti pembelajaran. Pada kegiatan ini guru dan peserta didik mencari informasi tentang materi Pancasīla Buddhis berdasarkan pengalamannya sehari-hari. Setelah itu, guru membimbing peserta didik untuk membuat diskusi berdasarkan kelompok masing-masing mengenai contoh pelanggaran Pancasila Buddhis dan akibatnya. Guru menyampaikan materi dengan menerapkan metode Contextual Teaching and Learning (CTL) peserta didik 
lebih paham karena materi dikaitkan dengan pemahaman dan pengalaman peserta didik sehingga tidak hanya guru yang aktif tetapi peserta didik harus lebih aktif namun ada beberapa peserta didik yang belum aktif mengikuti pembelajaran pendidikan agama Buddha.

Tahap akhir dari pertemuan pembelajaran pertemuan kedua adalah melaksanakan Post Test yang sama soalnya dengan butir soal Pre Test dan angket keaktifan peserta didik. Proses pembelajaran ini diakhiri dengan pembacaan Doa Namakārapātha dan ditutup dengan salam Buddhis.

\section{Observasi}

Tahap observasi ini dilakukan bersamaan dengan proses tindakan dilakukan yang ditujukkan dengan kegiatan proses mengamati semua hal yang berhubungan dengan mencatat hal-hal penting yang terjadi pada proses tindakan pada pembelajaran dengan menerapkan metode Contextual Teaching and Learning (CTL) serta mencatat kendala-kendala yang terjadi maupun permasalahan baru yang muncul pada proses pembelajaran.

\section{Refleksi}

Setelah selesai melaksanakan proses pembelajaran siklus I peneliti dan guru mendiskusikan hasil pengamatan pada pelaksanaan siklus I yang selanjutnya digunakan sebagai dasar untuk melakukan perbaikan pada siklus II. Hasil diskusi tersebut adalah:

a. Keterampilan guru dalam proses belajar mengajar
1) Guru harus membimbing peserta didik dalam kegiatan pembukaan seperti memimpin Doa Namakārapātha secara bergantian sehingga semua peserta didik ikut aktif dan mengikuti secara serius

2) Guru masih harus membimbing peserta didik dalam kelompok belajar di kelas

3) Guru masih harus meningkatkan pemodelan dalam proses mengajar sehingga peserta didik lebih cepat memahami materi di bandingkan dengan cara peserta didik di suruh membaca karena ada suatu permasalahan dengan adanya peserta didik yang belum lancar membaca

4) Guru harus lebih memperhatikan RPP dalam proses pembelajaran.

b. Pengamatan keaktifan peserta didik

Pada umumnya peserta didik tekun dan rajin mengikuti pembelajaran kecuali tidak masuk karena sakit, namun ada beberapa hal yang harus ditingkatkan yaitu:

1) Keberanian untuk bertanya masih kurang

2) Keberanian untuk menjawab pertanyaan guru masih kurang

3) Keberanian untuk berbicara di depan kelas masih kurang

4) Keberanian untuk berpendapat masih kurang

5) Memiliki ide sendiri untuk mencari pengetahuan pada sumber lain dan juga mencatat hal-hal penting yang di sampaikan guru belum ada 
c. Hasil Pre Test dan Post Test

Berdasarkan kegiatan Pre Test dan

Post Test yang telah dilaksanakan pada siklus I, hasil belajar peserta didik menjadi lebih baik, meskipun masih ada beberapa yang belum memenuhi Kriteria Kelulusan Minimun (KKM) pada jenjang pendidikan SMPN 2 Keling kelas VII tahun ajaran 2015/2016 mata pelajaran Pendidikan agama Buddha adalah 76. Jadi, pada saat Pre Test dari keseluruhan peserta didik ada 5 (50\%) yang belum memenuhi KKM, sedangkan pada saat Post Test 7 dari 10 peserta didik atau $70 \%$ sudah memenuhi KKM.

\section{Hasil Wawancara Siklus I}

\section{a. Wawancara Dengan Guru}

Berdasarkan hasil wawancara bahwa sangat terbantu dengan proses pembelajaran dengan menerapkan model Contextual Teaching and Learning (CTL) karena peserta didik sangat aktif dalam menemukan pengetahuan baru melalui pembelajaran yang mengaitkan anatara materi yang disampaikan dengan pengalaman peserta didik dalam kehidupan sehari-hari.

\section{b.Wawancara Dengan Peserta didik}

Pada proses pembelajaran pendidikan agama Buddha Kelas VII dengan menerapkan model Cntextual Teaching and Learning (CTL) pada materi Pancasīla Buddhis. Peserta didik sangat senang dan semangat belajar dibandingkan dengan model sebelumnya.

\section{Hasil Analisis Siklus I}

a. Hasil Observasi proses pembelajaran
Pada siklus I sudah menunjukkan ada perubahan terhadap keaktifan proses pembelajaran. Namun, masih ada kegiatan pembelajaran yang masih perlu diperbaiki, seperti:

- Kegiatan Pendahuluan: peserta didik sudah aktif memimpin Doa Namakārapātha namun belum secara bergantian.

- Kegiatan Eksplorasi: guru masih kurang dalam menginformasikan tujuan dan latar belakang pembelajaran, serta masih jarang memberikan umpan balik terhadap peserta didik

- Kegiatan Elaborasi: guru sudah memberikan kesempatan kepada peserta didik untuk bertanya dan berpendapat, namun tidak semua dari peserta didik berani untuk bertanya.

- Kegiatan Konfirmasi: guru belum memberikan kesimpulan terhadap apa yang sudah dipelajari agar peserta didik dengan mudah memahami materi yang disampaikan.

- Kegiatan Penutup: peserta didik sudah berani memimpin Doa Namakārapātha, namun masih belum serius, suka bercanda dalam pelaksanaannya.

b. Nilai Observasi Keaktifan Peserta didik

Tabel 1. Hasil Observasi Keaktifan Peserta Didik pada Siklus I

\begin{tabular}{|c|c|c|c|c|}
\hline No & Nama & NIS & Jml & Kriteria \\
\hline 1 & $\begin{array}{ll}\text { Diana } & \text { Dewi } \\
\text { Kalyani } & \end{array}$ & 0938 & 27 & Baik \\
\hline 2 & Heri Prasetiyo & 0942 & 15 & Kurang \\
\hline 3 & Jayadi & 0944 & 13 & kurang \\
\hline 4 & $\begin{array}{l}\text { Nyana } \\
\text { Satria }\end{array}$ & 0950 & 29 & Baik \\
\hline 5 & $\begin{array}{ll}\text { Sefia } & \text { Putri } \\
\text { Lestari } & \end{array}$ & 0953 & 22 & Cukup \\
\hline 6 & Susilo Adinoto & 0954 & 21 & Cukup \\
\hline 7 & $\begin{array}{l}\text { Dirga Yuka } \\
\text { Okta } \\
\text { Adhiviyanto }\end{array}$ & 0961 & 29 & Baik \\
\hline
\end{tabular}




\begin{tabular}{|c|l|c|c|c|}
\hline 8 & $\begin{array}{l}\text { Heru Budhi } \\
\text { Wibowo }\end{array}$ & 0966 & 16 & kurang \\
\hline 9 & Novita Ayumi & 0970 & 23 & Cukup \\
\hline 10 & $\begin{array}{l}\text { Susila } \\
\text { Widhiyanti }\end{array}$ & 0975 & 18 & Cukup \\
\hline
\end{tabular}

Sumber: Diolah Oleh Peneliti

Berdasarkan hasil dari lembar observasi keaktifan peserta didik dalam proses pembelajaran pendidikan agama Buddha pada materi Pancasīla Buddhis dengan menerapkan model pembelajaran Contextual Teaching and Learning (CTL) memperoleh hasil yang belum maksimal karena hanya 3 peserta didik yang mendapatkan kriteria baik. dengan demikian maka peneliti melakukan tindakan selanjutnya dengan melakukan tindakan siklus II.

\section{c. Ketuntasan Hasil Belajar Peserta didik}

Nilai Pres Test peserta didik pada kegiatan pembelajaran Siklus I yaitu 50\% dengan 5 peserta didik yang tuntas memperoleh nilai diatas KKM, 50\% lainnya yaitu 5 peserta didik tidak tuntas karena nilai yang diperoleh dibawah KKM. Nilai yang diperoleh adalah terendah 30 , sedangkan nilai KKM yang ditentukan adalah 76 .

Nilai Post Test yang diperoleh peserta didik pada proses pembelajaran Siklus I yaitu 3 atau $30 \%$ peserta didik tidak tuntas dengan memperoleh nilai dibawah KKM dan mengalami peningkatan dengan 7 atau $70 \%$ peserta didik memperoleh nilai diatas KKM.

\section{Tabel 2. Ketuntasan Hasil Belajar Peserta Didik} Pada Siklus I

Asosiasi Dosen \& Unit Penelitian dan Pengabdian Masyarakat
Pre Test

\begin{tabular}{|c|c|c|c|}
\hline No & Kriteria & $\begin{array}{c}\text { Freku } \\
\text { ensi }\end{array}$ & $\begin{array}{c}\text { Pres } \\
\text { entas } \\
\text { e }\end{array}$ \\
\hline 1 & $\begin{array}{c}\text { Peserta Didik } \\
\text { Tuntas }\end{array}$ & 5 & $50 \%$ \\
\hline 2 & $\begin{array}{c}\text { Peserta Didik } \\
\text { Tidak Tuntas }\end{array}$ & 5 & $50 \%$ \\
\hline
\end{tabular}

Sumber: Diolah oleh Peneliti

Post Test

\begin{tabular}{|c|c|c|c|}
\hline No & Kriteria & $\begin{array}{c}\text { Freku } \\
\text { ensi }\end{array}$ & $\begin{array}{c}\text { Pres } \\
\text { entas } \\
\text { e }\end{array}$ \\
\hline 1 & $\begin{array}{c}\text { Peserta didik } \\
\text { Tuntas }\end{array}$ & 7 & $70 \%$ \\
\hline 2 & $\begin{array}{c}\text { Peserta didik } \\
\text { Tidak Tuntas }\end{array}$ & 3 & $30 \%$ \\
\hline
\end{tabular}

Sumber: Diolah oleh Peneliti

Berdasarkan hasil pre test dan post yang dilakukan pada siklus I telah terjadi peningkatan peserta didik yang tuntas. Peningkatan tersebut dapat dilihat pada grafik dibawah ini:

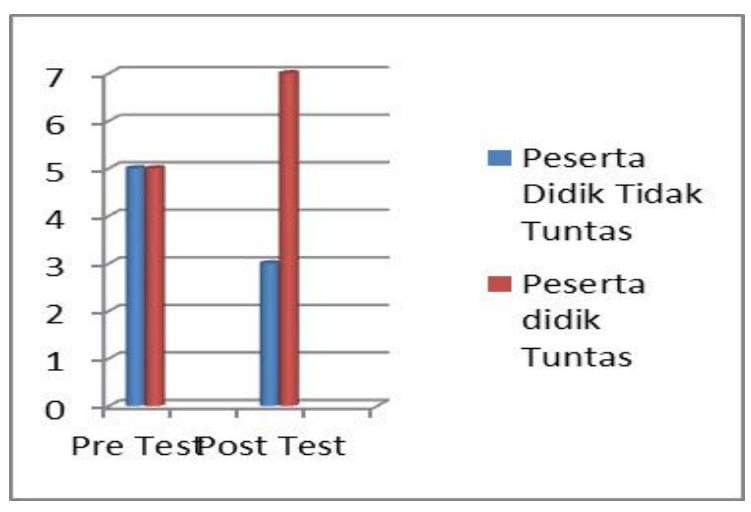

Sumber data: diolah oleh Peneliti

\section{Gambar 1. Grafik ketuntasan hasil belajar peserta didik siklus I}

Berikut data Nilai hasil Pre Test dan Post

Test Peserta didik pada pembelajaran Siklus I:

Tabel 3. Hasil Nilai Pre Test Dan Post Test Siklus I 


\begin{tabular}{|c|c|c|c|c|}
\hline \multirow[b]{2}{*}{ No } & \multirow[b]{2}{*}{ Nama } & \multirow[b]{2}{*}{ NIS } & \multicolumn{2}{|c|}{ Siklus I } \\
\hline & & & $\begin{array}{l}\text { Pre } \\
\text { Test }\end{array}$ & $\begin{array}{l}\text { Post } \\
\text { Test }\end{array}$ \\
\hline 1 & $\begin{array}{ll}\text { Diana } & \text { Dewi } \\
\text { Kalyani } & \\
\end{array}$ & 0938 & 90 & 100 \\
\hline 2 & Heri Prasetiyo & 0942 & 30 & 70 \\
\hline 3 & Jayadi & 0944 & 30 & 50 \\
\hline 4 & $\begin{array}{ll}\text { Nyana } & \text { Badra } \\
\text { Satria } & \end{array}$ & 0950 & 80 & 100 \\
\hline 5 & $\begin{array}{ll}\text { Sefia } & \text { Putri } \\
\text { Lestari } & \\
\end{array}$ & 0953 & 80 & 100 \\
\hline 6 & Susilo Adinoto & 0954 & 70 & 70 \\
\hline 7 & $\begin{array}{l}\text { Dirga Yuka Okta } \\
\text { Adhiviyanto }\end{array}$ & 0961 & 80 & 90 \\
\hline 8 & $\begin{array}{ll}\text { Heru } & \text { Budhi } \\
\text { Wibowo } & \end{array}$ & 0966 & 70 & 80 \\
\hline 9 & Novita Ayumi & 0970 & 100 & 100 \\
\hline 10 & Susila Widhiyanti & 0975 & 70 & 100 \\
\hline
\end{tabular}

Berdasarkan hasil Post test, dapat di ketahui bahwa 7 dari 10 peserta didik tuntas dengan memperoleh nilai diatas KKM dengan presentase $30 \%$ peserta didik belum mencapai ketuntasan. Hasil tersebut menggambarkan bahwa permasalahan dalam proses belajar mengajar pada pendidikan agama Buddha pada materi Pancasila Buddhis di SMP Negeri 2 Keling belum teratasi dan perlu untuk melakukan tindakan lanjutan.

\section{Deskripsi Siklus II}

\section{Perencanaan Siklus II}

Sebelum tindakan pada siklus II dilaksanakan didalam kelas peneliti dan juga guru pendidikan agama Buddha yang menerapkan model pembelajaran model Contextual Teaching and Learning (CTL) mempersiapkan segala sesuatu yang dibutuhkan untuk menunjang proses pembelajaran sesuai dengan materi Pancasīla Buddhis, yaitu Rencana Pelaksanaan Pembelajaran (RPP) dengan model Contextual Teaching and Learning (CTL), instrumen berupa Pre tes dan Post tes, observasi, lembar wawancara guru maupun peserta didik, serta lembar observasi keaktifan peserta didik.

\section{Pelaksanaan Siklus II}

Proses pelaksanaan tindakan pada siklus II terdiri dari 2 kali pertemuan yaitu tindakan pada kelas VII.A dan VII.B yang dilaksanakan pada hari Senin tanggal 11 April 2016 (Pre test) dan Senin tanggal 25 April 2016 (Post test) dengan alokasi waktu masing-masing 2 x 40 Menit.

a) Pertemuan pertama

Pada pertemuan pertama pada siklus II guru dan peserta didik membuka dengan Doa Namakārapātha yang dipimpin oleh salah satu dari peserta didik sehingga ada keaktifan dalam kegiatan pendahuluan. Setelah itu memberikan salam Buddhis, mengabsensi peserta didik, menyampaikan tujuan pembelajaran, serta memberikan motivasi. berkolaborasi dengan Guru untuk memberikan pre test II.

Pada pertemuan pertama pada siklus II ini guru menekankan pada penyampaian contoh-contoh yang berhubungan dengan materi Pancasīla Buddhis baik dengan kejadian di media sosial maupun dari pengalaman peserta didik Tahap terakhir yaitu guru memberikan kesimpulan dan memberikan tugas agar mempelajari materi yang berikutnya dirumah dilanjutkan dengan pembacaan Doa Namakārapātha yang dipimpin oleh salah satu peserta didik dan guru memberikan salam Buddhis.

b) Pertemuan kedua

Proses pembelajaran dilakukan dengan berkolaborasi antara guru dan peneliti dengan mengacu pada RPP dan juga model pembelajaran Contextual Teaching and Learing (CTL) Proses pembelajaran pada 
pertemuan kedua diawali dengan kegiatan pendahuluan yaitu Doa Namakārapātha yang dipimpin oleh salah satu dari peserta didik, guru memberikan salam Buddhis, mengabsensi kehadiran peserta didik serta menyampaikan apersepsi. Kegiatan inti pada pertemuan ini guru membagi kelompok untuk melakukan diskusi mengenai pelanggaran Sïla dan akibatnya. Hasil diskusi tersebut mereka presentasikan didepan kelas dan sekelompok. Selanjutnya guru memberikan soal post test II sedangkan peneliti mengisi lembar penilian keaktifan peserta didik. Setelah soal post test selesai guru memberikan kesempatan bertanya tentang materi yang belum dipahami kemudian bersama dengan peserta didik membuat kesimpulan terhadap apa yang sudah dipelajari pada pertemuan tersebut. Tahap akhir yaitu penutup dengan Doa Namakārapātha yang dipimpin oleh salah satu dari peserta didik dan diakhiri dengan salam Buddhis.

\section{Observasi}

Tahap observasi (pengamatan) ini dilakukan bersamaan dengan proses tindakan yang ditujukkan dengan peningkatan keaktifan dalam proses pembelajaran pada siklus I ke siklus II. Kegiatan pembelajaran pendidikan agama Buddha dengan penerapan model pembelajaran Contextual Teaching and Learning (CTL) pada penelitian di kelas VII dapat berjalan dengan baik walaupun masih ada beberapa peserta didik harus lebih diperhatikan lagi dalam proses pembelajaran di kelas.

Hasil observasi pada proses pembelajaran siklus II terlaksana dengan baik mulai dari pembacaan Doa Namakarāpātha yang dipimpin secara bergiliran oleh peserta didik, penyampaian salam Buddhis, mengabsensi kehadiran peserta didik. Proses pembelajaran dimulai dengan penyampaian tujuan pembelajaran yang harus dicapai pada materi Pancasila Buddhis kemudian guru memberikan apersepsi mengenai materi yang sudah disampaikan sebelumnya, peserta didik antusias dan turut aktif menjawab setiap pertanyaan yang berikan. Proses pembelajaran pada siklus dua berjalan secara sistematis sesuai dengan RPP yang sudah dibuat. Peserta didik mengalami peningkatan keaktifan belajar dikelas dengan memperhatikan guru dan bertanya dan mengeluarkan pendapat berupa pengalaman yang sudah dialami sesuai dengan materi yang disampaikan guru. Selain itu juga antusias dalam mengerjakan soal yang diberikan setelah materi secara keseluruhan sudah disampaikan, serta ikut aktif dalam mencari pengetahuan diluar sekolah dengan mengkuti belajar kelompok untuk memecahkan permasalahan yang diberikan sebagai tugas di rumah. Kemudian pembelajaran diakhiri dengan Doa Namakarāpātha yang dipimpin oleh salah satu dari peserta didik dan guru mengucapkan salam Buddhis.

\section{Refleksi}

Guru dan peneliti mendiskusikan hasil observasi untuk mengetahui sejauh mana peningkatan dari tindakan siklus 1 sampai siklus II. Hasil diskusi tersebut adalah :

a. Pengamatan keterampilan guru dalam proses pembelajaran

1) Keterampilan guru dalam kegiatan pendahuluan sudah cukup baik dan berjalan sesuai RRP yang ada. Hal tersebut terlihat dari hasil lembar observasi pembelajaran. 
2) Guru lebih memahami cara penyampaian materi sesuai dengan kemampuan peserta didik

3) Guru banyak memberikan contoh dari pengalaman peserta didik dengan cara berdiskusi bersama

\section{b. Pengamatan keaktifan peserta didik}

Keaktifan peserta didik dalam proses pembelajaran sudah dikatakan baik mulai dari kehadiran dalam belajar dikelas, kemudian keaktifan mengikuti proses pembelajaran. Proses pembelajaran dimulai dengan kegiatan pendahuluan peserta didik aktif mengikuti dengan cara memimpin Doa Namakarāpātha tanpa ditujuk oleh guru dan juga aktif menjawab pertanyaan sebagai apersepsi pada pertemuan sebelumnya.

Kegiatan inti juga antara guru dan peserta didik sama-sama aktif. Peserta didik mengalami peningkatan keaktifan mulai dari mengajukan pertanyaan atau mengemukakan pendapat, berani berbicara didepan kelas, serta mencari pengetahuan dengan cara mengemukakan pengalaman yang dilakukan sesuai materi yang disampaikan.

\section{c. Hasil Pre Test dan Post Test}

Berdasarkan hasil Pre Test dan Post Test yang telah dilaksanakan pada siklus II mengalami peningkatan yang sangat baik. Peserta didik mengalami peningkatan keberhasilan dengan nilai diatas KKM walaupun ada satu orang yang belum maksimal karena keterbatasan dalam membaca.

\section{Hasil Wawancara Siklus II}

\section{a. Wawancara dengan guru}

Berdasarkan kegiatan wawancara yang telah peneliti lakukan pada guru pendidikan agama Buddha SMPN 2 Keling dapat disimpulkan bahwa dengan penerapan model Contextual Teaching and Learnng (CTL) dapat meningkatkan keaktifan dan hasil belajar peserta didik. Guru menjadi terbantu dalam penyampaian materi sehingga peserta didik lebih paham dengan materi yang disampaikan.

\section{b. Wawancara Dengan Peserta didik}

Berdasarkan wawancara dengan peserta didik pada proses pembelajaran pendidikan agama Buddha Kelas VII dengan menerapkan metode Cntextual Teaching and Learning (CTL) pada materi Pancasīla Buddhis peserta didik mejawab bahwa pembelajaran menjadi lebih menyenangkan, peserta didik aktif dalam kegiatan pembelajaran dengan cara bertanya ketika ada materi yang belum dipahami.

\section{Hasil Analisi siklus II}

\section{a. Hasil Observasi Proses Pembelajaran}

Hasil observasi proses pembelajaran pada siklus II menunjukkan peningkatan keaktifan guru dalam melaksanakan kegiatan proses pembelajaran dengan baik, seperti:

- Kegiatan pendahuluan: Guru dan peserta didik sama-sama aktif . guru melaksanakan apersepsi dengan baik dan peserta didik bergantian memimpin Doa Namakārapātha.

$\begin{array}{llr}\text { - Kegiatan Eksplorasi: } & \text { Guru } \\ \text { melaksanakan dengan baik } & \text { sesuai }\end{array}$ 
dengan RPP yang dibuat yang terpenting adalah menyampaikan tujuan yang harus dicapai pada materi dalam proses pembelajaran.

- Kegiatan Elaborasi: Guru sudah memberikan waktu dan kesempatan kepada peserta didik untuk bertanya atau berpendapat.

- Kegiatan Konfirmasi: Guru sudah melaksanakan dengan baik dan menyimpulkan apa yang sudah diajarkan.

- Kegiatan Penutup: Guru dan peserta didik melaksanakan dengan baik.

\section{b. Nilai Observasi Keaktifan Peserta didik}

Hasil observasi keaktifan peserta didik pada proses pembelajaran pendidikan agama Buddha pada materi Pancasīla Buddhis dengan menerapkan model pembelajaran Contextual Teaching and Learning (CTL) di SMP Negeri 2 Keling pada siklus I diperoleh hasil sebagai berikut:

\section{Tabel 4. Hasil Observasi Keaktifan Peserta}

Didik pada Siklus II

\begin{tabular}{|c|c|c|c|c|}
\hline No & Nama & NIS & $\mathbf{J m l}$ & $\begin{array}{c}\text { Krite } \\
\text { ria }\end{array}$ \\
\hline 1 & $\begin{array}{ll}\text { Diana } & \text { Dewi } \\
\text { Kalyani } & \end{array}$ & 0938 & 29 & Baik \\
\hline 2 & Heri Prasetiyo & 0942 & 24 & Baik \\
\hline 3 & Jayadi & 0944 & 24 & Baik \\
\hline 4 & $\begin{array}{ll}\text { Nyana } & \text { Badra } \\
\text { Satria } & \\
\end{array}$ & 0950 & 30 & Baik \\
\hline 5 & $\begin{array}{ll}\text { Sefia } & \text { Putri } \\
\text { Lestari } & \\
\end{array}$ & 0953 & 28 & Baik \\
\hline 6 & Susilo Adinoto & 0954 & 29 & Baik \\
\hline 7 & $\begin{array}{l}\text { Dirga Yuka Okta } \\
\text { Adhiviyanto }\end{array}$ & 0961 & 30 & Baik \\
\hline 8 & $\begin{array}{ll}\text { Heru } & \text { Budhi } \\
\text { Wibowo } & \\
\end{array}$ & 0966 & 24 & Baik \\
\hline 9 & Novita Ayumi & 0970 & 30 & Baik \\
\hline 10 & Susila & 0975 & 27 & Baik \\
\hline
\end{tabular}

Asosiasi Dosen \& Unit Penelitian dan Pengabdian Masyarakat
Widhiyanti

Berdasarkan hasil dari lembar observasi keaktifan peserta didik dalam proses pembelajaran pendidikan agama Buddha pada materi Pancasīla Buddhis dengan menerapkan model pembelajaran Contextual Teaching and Learning (CTL) memperoleh hasil yang sangat baik. Peserta didik berani untuk bertanya dan mengungkapkan pendapat serta ikut aktif dalam diskusi dengan guru maupun peserta didik lainnya. Berdasarkan data tersebut membuktikan bahwa penerapan model pembelajaran Contextual Teaching and Learning (CTL) mampu meningkatkan keaktifan peserta didik dengan ada peringkat baik dan mampu mengubah salah satu peserta didik yang mempunyai keterbatasan membaca ikut aktif seperti temannya yang lain karena materi dikaitkan dengan pengalaman peserta didik dan contoh kejadian yang nyata pada kehidupan seharihari.

\section{c. Ketuntasan Hasil Belajar Peserta didik}

Nilai Pres Test peserta didik pada kegiatan pembelajaran Siklus II yaitu $80 \%$ dengan 8 peserta didik yang tuntas memperoleh nilai diatas KKM, namun 20\% lainnya yaitu 2 peserta didik tidak tuntas karena nilai yang diperoleh dibawah KKM. Nilai terendah yang diperoleh adalah 50, sedangkan nilai KKM yang ditentukan adalah 76. Nilai Post Test yang diperoleh peserta didik pada proses pembelajaran Siklus II yaitu $100 \%$ atau 10 peserta didik tuntas dengan memperoleh nilai diatas KKM mengalami peningkatan $20 \%$ dari Pre 
Test. Data tersebut disajikan dalam bentuk tabel sebagai berikut:

Tabel 6. Hasil Nilai Pre Test Dan Post Test

Tabel 5. Ketuntasan Hasil Belajar Peserta Didik

Pada Siklus II

Pre Test

\begin{tabular}{|c|c|c|c|}
\hline No & Kriteria & $\begin{array}{c}\text { Freku } \\
\text { ensi }\end{array}$ & $\begin{array}{c}\text { Present } \\
\text { ase }\end{array}$ \\
\hline 1 & $\begin{array}{c}\text { Peserta didik } \\
\text { Tuntas }\end{array}$ & 8 & $80 \%$ \\
\hline 2 & $\begin{array}{c}\text { Peserta didik } \\
\text { Tidak Tuntas }\end{array}$ & 2 & $20 \%$ \\
\hline
\end{tabular}

Sumber: Diolah oleh Peneliti

Post Test

\begin{tabular}{|c|c|c|c|}
\hline No & Kriteria & Frekuensi & $\begin{array}{c}\text { Presen } \\
\text { tase }\end{array}$ \\
\hline 1 & $\begin{array}{c}\text { Peserta } \\
\text { didik } \\
\text { Tuntas }\end{array}$ & 10 & $100 \%$ \\
\hline 2 & $\begin{array}{c}\text { Peserta } \\
\text { didik Tidak } \\
\text { Tuntas }\end{array}$ & 0 & $0 \%$ \\
\hline
\end{tabular}

Sumber: Diolah oleh Peneliti

Berdasarkan hasil pre test dan post yang dilakukan pada siklus II telah terjadi peningkatan peserta didik yang tuntas. Peningkatan tersebut dapat dilihat pada grafik dibawah ini:

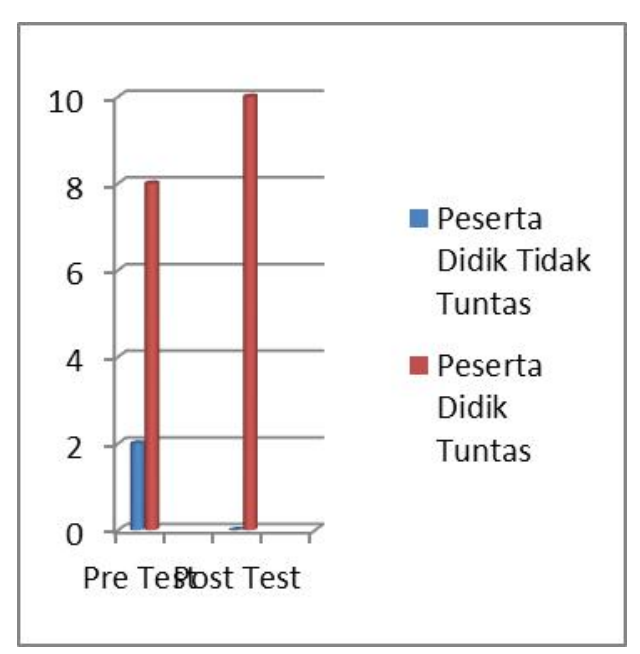

Sumber data: diolah oleh peneliti

\section{Gambar. 5 Grafik ketuntasan hasil belajar peserta didik siklus II.}

Berikut data Nilai hasil Pre Test dan Post Test Peserta didik pada pembelajaran Siklus II:
Siklus II

\begin{tabular}{|c|c|c|c|c|}
\hline \multirow[b]{2}{*}{ No } & \multirow[b]{2}{*}{ Nama } & \multirow[b]{2}{*}{ NIS } & \multicolumn{2}{|c|}{ Siklus II } \\
\hline & & & Pre Test & $\begin{array}{l}\text { Post } \\
\text { Test }\end{array}$ \\
\hline 1 & $\begin{array}{c}\text { Diana Dewi } \\
\text { Kalyani }\end{array}$ & 0938 & 100 & 100 \\
\hline 2 & $\begin{array}{l}\text { Heri } \\
\text { Prasetiyo }\end{array}$ & 0942 & 50 & 80 \\
\hline 3 & Jayadi & 0944 & 50 & 80 \\
\hline 4 & $\begin{array}{l}\text { Nyana Badra } \\
\text { Satria }\end{array}$ & 0950 & 100 & 100 \\
\hline 5 & $\begin{array}{l}\text { Sefia } \\
\text { Lestari }\end{array}$ & 0953 & 90 & 100 \\
\hline 6 & $\begin{array}{l}\text { Susilo } \\
\text { Adinoto }\end{array}$ & 0954 & 80 & 100 \\
\hline 7 & $\begin{array}{l}\text { Dirga Yuka } \\
\text { Okta } \\
\text { Adhiviyanto }\end{array}$ & 0961 & 90 & 100 \\
\hline 8 & $\begin{array}{l}\text { Heru Budhi } \\
\text { Wibowo }\end{array}$ & 0966 & 90 & 100 \\
\hline 9 & $\begin{array}{l}\text { Novita } \\
\text { Ayumi }\end{array}$ & 0970 & 100 & 100 \\
\hline 10 & $\begin{array}{l}\text { Susila } \\
\text { Widhiyanti }\end{array}$ & 0975 & 90 & 100 \\
\hline
\end{tabular}

Sumber: Diolah oleh Peneliti

Berdasarkan hasil Post test, dapat di ketahui bahwa hasil belajar 10 peserta didik sudah tuntas dengan memperoleh nilai diatas KKM dengan presentase 100\% peserta didik mencapai ketuntasan. Hasil tersebut menggambarkan bahwa permasalahan dalam proses belajar mengajar pada pendidikan agama Buddha pada materi Pancasīla Buddhis kelas VII SMPN 2 Keling teratasi dengan baik dan tidak ada tindakan selanjutnya.

\section{KESIMPULAN}

1. Penerapan model pembelajaran Contextual Teaching and Learning (CTL) mampu meningkatkan keaktifan peserta didik dalam pembelajaran pendidikan agama Buddha materi Pancasīla Buddhis. Kegiatan pembelajaran 
dilakukan dengan cara menerapkan komponen dari model pembelajaran Contextual Teaching and Learning (CTL) yaitu (a) konstruktivisme (membangun) pengetahuan sendiri melalui pengalaman sehari-hari, (b) Questioning (bertanya) dengan cara memberikan kesempatan untuk bertanya tentang materi yang belum dipahami, (c) Inquiry (menemukan) pengetahuan secara sistematis bukan dari hasil mengingat atau menghafal, (d) Learning Community (Masyarakat belajar) dengan cara belajar kelompok atau diskusi bersama, (e) Modelling (Pemodelan) yaitu guru memberikan materi dengan bantuan media sehingga peserta didik dapat memahami apa yang disampaikan guru, (f) Reflection (Refleksi) yaitu guru dan peserta didik melakukan tinjauan kembali terhadap apa yang dipelajari sebelumnya sehingga ada bahan untuk rencana perbaikan, (g) Authentic Assessment (penilaian sebenarnya) yaitu evaluasi guru dalam proses pembelajaran tidak hanya dengan test. Hasil penelitian menujukkan adanya peningkatan keaktifan peserta didik setelah diterapkan model pembelajaran Contextual Teaching and Learning (CTL) pada Siklus I dan Siklus II. Pada siklus I tiga peserta didik yang mendapatkan kriteria baik dan pada siklus II semua peserta didik mendapatkan kriteria baik.

2. Penerapan model Contextual Teaching and Learning (CTL) meningkatkan hasil belajar peserta didik dengan mencapai batas tuntas minimal terus meningkat dari tiap siklus. Pada siklus I mencapai nilai batas minimal sebanyak 7 peserta didik (70\%), sebelumnya saat pra siklus peserta didik yang mencapai nilai batas tuntas minimal sebanyak 4 (40\%). Terjadi peningkatan (30\%). Pada siklus II peserta didik yang telah mencapai nilai batas tuntas minimal sebanyak 10 peserta didik (100\%) terjadi peningkatan sebanyak 3 peserta didik (30\%). Dengan demikian dengan menerapkan model pembelajaran Contextual Teaching and Learning (CTL) mampu meningkatkan keaktifan dan hasil belajar peserta didik kelas VII SMPN 2 Keling pada materi Pancasīla Buddhis.

Berdasarkan hasil penelitian tindakan kelas yang dilaksanakan di SMPN 2 Keling Kabupaten Jepara, pada mata pelajaran pendidikan agama Buddha Kelas VII, ada beberapa saran yang dapat dipergunakan sebagai bahan pertimbangan untuk perubahan sistem pembelajaran yang lebih baik antara lain:

1. Guru hendaknya mampu menerapkan model pembelajaran Contextual Teaching and Learning (CTL) dalam pembelajaran yang dapat meningkatkan keaktifan dan hasil belajar peserta didik pada pembelajaran pendidikan agama Buddha.

2. Guru mampu merancang kegiatan pembelajaran kontekstual sehingga peserta didik aktif dalam proses pembelajaran.

3. Guru hendaknya mampu mengoptimalkan media yang ada untuk menerapkan model pembelajaran Contextual Teaching and Learning (CTL) seperti komponen pemodelan (Modelling) sehingga siswa menjadi lebih semangat mengikuti pembelajaran agama Buddha.

4. Guru hendaknya tidak mendominasi jalannya proses pembelajaran namun memberikan kesempatan kepada peserta didik untuk aktif membangun pengetahun sendiri.

5. Siswa diharapkan lebih semangat lagi untuk mengikuti pembelajaran pendidikan agama Buddha.

6. Kepada sekolah disarankan memberikan dukungan secara optimal, memberikan fasilitas 
sarana dan prasarana baik, sehingga guru dan peserta didik dapat menjalankan proses pembelajaran dengan baik.

7. Kepada Dinas pendidikan Kabupaten Jepara disarankan agar sering mengadakan pelatihanpelatihan mengenai model pembelajaran, sehingga dapat memberikan pengetahuan kepada guru yang dapat diterapkan kepada peserta didik sehingga meningkatkan keaktifan dan hasil belajar yang lebih baik.

\section{DAFTAR PUSTAKA}

Arikunto, S .(2013). Prosedur Penelitian, suatu Pendekatan Praktik. Jakarta: Rineka Cipta.

. (2013). Dasar-Dasar Evaluasi Pendidikan. Jakarta: Bumi Aksara.

Fauziah, Irma. (2012). Meningkatkan Hasil Belajar dengan Menggunakan Pendekatan Kontextual Teaching and Learning (CTL) pada Pembelajaran Matematika Tentang Konsep Pecahan. Skripsi. Bandung:
Universitas Pendidikan Indonesia. Tidak diterbitkan.

Kunandar. (2014). Penilaian Autentik (Penilian Hasil Belajar Peserta Didik Berdasarkan Kurikulum 2013). Jakarta: Rajawali pers.

Majid, A. (2014). Strategi Pembelajaran. Bandung: PT Remaja Rosdakarya.

Riyanto.Y. (2009). Paradigma Baru pembelajaran Sebagai Referensi bagi Guru Pendidik dalam Implementasi Pembelajaran yang Efektif dan Berkualitas. Jakarta: Kencana Prenada Media Goup.

Sanjaya, W. (2006). Startegi Pembelajaran Berorientasi Standar Proses Pendidikan. Jakarta: Kencana Prenadamedia Grup.

Sardiman, A. M. (2011). Interaksi dan Motivasi Belajar Mengajar. Jakarta: Raja Grafindo Persada.

Slameto (2010). Belajar dan Faktor-Faktor yang Mempengaruhinya. Jakarta: Rineka Cipta.

Sudjana, N. (2012). Penilaian hasil proses belajar mengajar. Bandung: PT Remaja Rosdakarya.

Tim Reality. (2008). Kamus Terbaru Bahasa Indonesis. Surabaya: Reality Publisher. 